Interactive comment on "Assessing the effect of lithological setting, block characteristic and slope topography on the runout length of rockfalls in the Alps and on the La Réunion island" by Kerstin

\title{
Wegner et al.
}

Kerstin Wegner et al.

kwegner@ku.de

Received and published: 18 December 2020

The comment was uploaded in the form of a supplement:

https://nhess.copernicus.org/preprints/nhess-2020-322/nhess-2020-322-AC2-

supplement.pdf

Printer-friendly version

Interactive comment on Nat. Hazards Earth Syst. Sci. Discuss., https://doi.org/10.5194/nhess2020-322, 2020.
Discussion paper

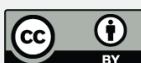

